\title{
Rehabilitation Proposal for a Rural Settlement Affected By the Fundão Dam Tailings (Mariana-Brazil): A Study Case
}

\author{
Bárbara Carolina Soares Fortes ${ }^{1}$, Maria Rita Scotti ${ }^{2}$, Maria Cristina Villefort ${ }^{3}$, Stael Alvarenga ${ }^{4}$ \\ ${ }^{1}$ Escola de Arquitetura /UFMG Programa Pós Graduação em Ambiente Construído e Patrimônio Sustentável. \\ R. Paraíba, 697, Belo Horizonte, Brasil. \\ barbaracsfortes@ arq.mest.ufmg.br; mrsm.ufmg@gmail.com \\ ${ }^{2}$ Depto of Botany /ICB/UFMG \\ Av Antonio Carlos 6627, Belo Horizonte, Brasil \\ 3mcrisvt@gmail.com \\ ${ }^{4}$ staelalvarenga@gmail.com
}

\begin{abstract}
The rupture of the Fundão dam in Mariana (Minas Gerais State, Brazil) spilled the tailings across the Doce River basin, whose main toxic compounds were sodium and ether-amine, severely affecting the vegetation and soil biota. These tailings with elevated sodium and ether-amines-ammonium contents reached several towns across the Doce River basin, such as Ipaba. In this study, we confirmed the highest levels of sodium and ammonium in riverine settlement sites at Ipaba, that may have compromised crop production and fishing activities. Previous results showed that the remediation of such toxic compounds, as well as the recovery of soil fertility, plant growth and agricultural production, may be feasible if adequate and goal-directed management procedures are employed. In addition, Ipaba settlements have faced the deleterious effect of flooding containing contaminated sediment on their cropping areas. In view of the key role of riparian buffer forests to remediate toxic compounds and also to protect cropping sites against flooding, we propose a sustainable rehabilitation plan for the settlements areas affected by the Fundão dam tailings based on: 1) the creation of a riparian forest under buffer zone systems to protect the riverine settlement sites; 2) the application of remediation strategies prior to forestry management and cropping activities in order to alleviate the dam tailing toxicity; 3) the creation of a technical training school and an association of settlers to provide them with knowledge, skills and self-sufficiency for the implementation of such rehabilitation plan. This study will hopefully aid settlers to properly manage their lands in a post-disaster scenario.
\end{abstract}

Keywords: Agroforestry, Landscape recovery, Remediation, Reclamation, Riparian Forest.

\section{Introduction}

In November 2015, the Fundão dam collapse spread 43 million m3 of tailings downslope across the Doce River basin (Fig. 1 A). The wave of tailings extended over around 11469 hectares of riparian forest belonging to the Brazilian Atlantic Forest biome, causing a severe loss of biodiversity [1], [2]. The impact of the dam tailings also compromised agricultural and fishing activities, as attested by both anecdotal registries of the local community and the literature [3]. The main environmental impact caused by the dam tailings was related to the high levels of ether-amine/ammonium and sodium found in the sediments, which are used in the iron ore beneficiation process by the Samarco mine [4], [5]. Meanwhile, the sediments showed low organic matter content and fertility levels, but no metal toxicity [2]. Metals in the sediments were registered at the same levels as preserved sites not affected by the dam tailings [2] and the regional background, both before [6] and after [7] the disaster. Despite the great impact of these contaminants over such a vast area [2], [8], [9] were able to establish a pioneer remediation model to reduce the ether-amine and sodium in a riparian area affected by contaminated sediment by using phyto- and physical-chemical co-strategies. These strategies were able to remediate and reclaim the affected site.

Ipaba is one of the municipalities that were severely affected by the Fundão dam tailings (Fig. 1 A, B1 and B2). This municipality comprises a total land area of $113,246 \mathrm{~km}^{2}$ with a population of 16,708 with a low per capita income, and the main economic activities are agro-pastoral and agroforestry [10]. At this location, there is a large rural settlement located in the margin of the Doce River, whose agricultural activity was severely impacted by the dam tailings (Fig. 1 B3). Besides, since the disaster, these areas have periodically suffered flooding containing contaminated sediments from the Doce river, 
further worsening their agricultural activity. However, the rehabilitation of riparian forests (RF) may assure ecosystem services related to land protection from the damage caused by flooding [11].

After the Fundão dam rupture, several families abandoned their land because it had become unproductive, and the rural exodus remains a serious concern for rural settlers for whom agricultural and fishing activities were their main economic provisions. Considering the possibility of remediation and rehabilitation of riparian buffer sites, as well as the recovery of crop production, the present study aims to evaluate the feasibility of recovering the rural settlers' properties in Ipaba under socio-economic and environmental aspects.

\section{Material and Methods}

\subsection{Study site}

The study site is located at Ipaba municipality $\left(19^{\circ} 26^{\prime} .29^{\prime \prime S} 42^{\circ} 24^{\prime} .36^{\prime \prime} \mathrm{W}\right)$, in the Minas Gerais State (Fig. 1 A and C), along the Doce River basin. Regarding soil fertility analyses, this site was compared to a severely degraded site (DS) located in Paracatu de Baixo District $\left(20^{\circ} 17^{\prime} 55.79^{\prime \prime S} 43^{\circ} 14^{\prime} 07.31 " \mathrm{~W}\right)$ which was also affected by the Fundão tailings

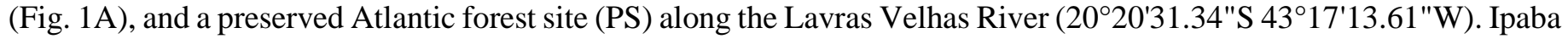
town with its settlements and afforestation sites along the Doce River are presented in Fig. 1 D.

\subsection{Experimental design for Physical and chemical soil analyses}

The study site (ES) is a settlement composed of 53 properties of 1.5 ha each, totalling 80.0 ha. For soil analysis, 3 mixed samples were collected at a depth of $20 \mathrm{~cm}$ from 15 of the settlement properties, totalling 45 samples, as well as 12 samples collected in the preserved (PS) and in the disturbed site (DS). The soil samples were analysed for their chemical properties [12].

\subsection{Economic and social assessments}

The economic data of the community of settlers were based on the Environmental Secretary data survey which registered the economic activity of 51 families in relation to agriculture and fishing production as well as the income per rural producer, before and after the Fundão dam disaster. The social data was based on interviews that aimed to assess the literacy index, level of schooling and recreation/sport activities of this population.

\subsection{Statistical analysis}

The soil variables were compared among the preserved, disturbed and settlement areas. ANOVA was used for the variables with normal distributions, and a Kruskal-Wallis test was used for the variables with non-normal distributions and multiple comparisons, using IBM-SPSS statistical software. 


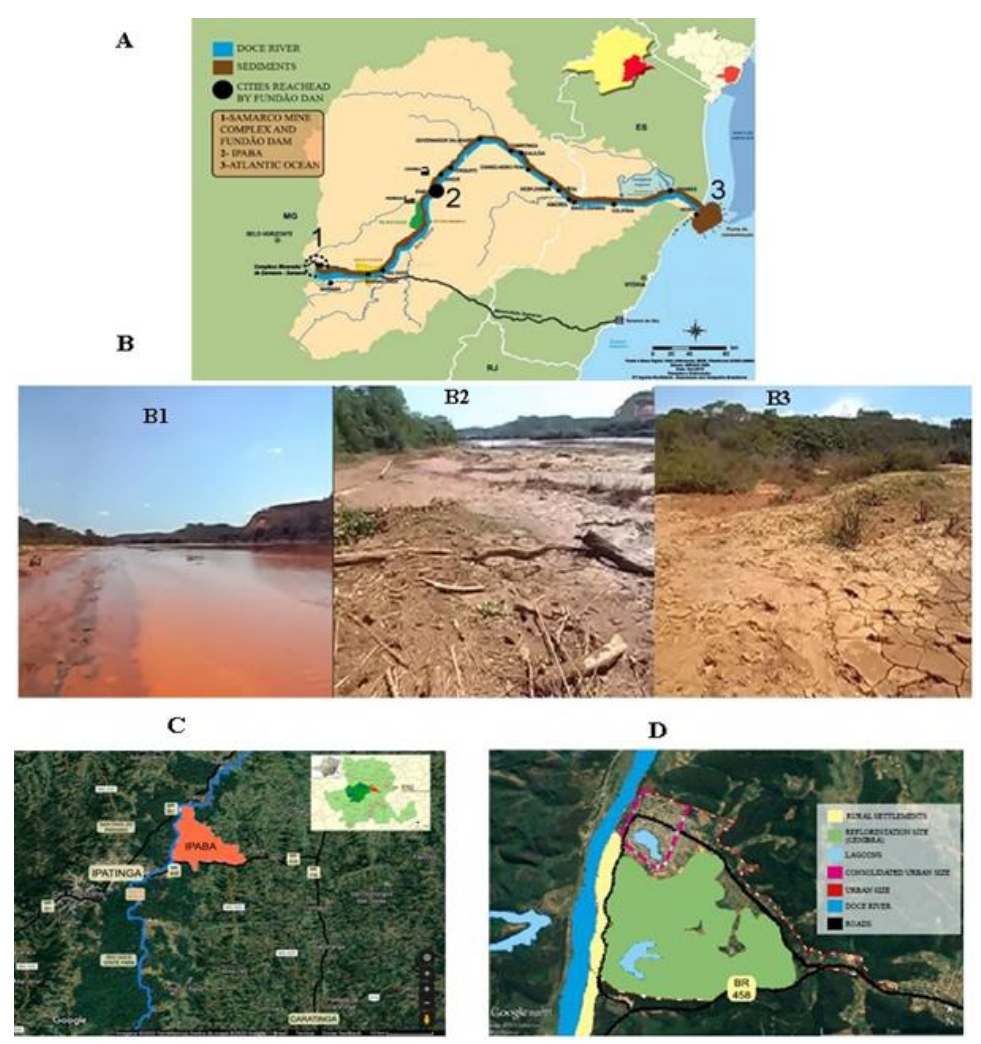

Fig. 1: A:.1- Locations of Samarco Mine and Fundão dam in Minas Gerais/ Brazil 2- Cities along Doce river basin reachead by Fundão dam tailing and IPABA, 3 Atlantic Ocean. 1 B1- Doce river in Ipaba cirty one week after Fundão dam rupture 1 B2 - Dam tailing covering riparian area in Ipaba city one week after Fundão disaster, 1 B3: Dam tailing covering the settlements site of Ipaba, C-Cities of "Steel Valey showing Ipaba location. D- Rural settlements of Ipaba in Urban area and closed to Reflorestation site of Cenibra.

\section{Results and discussion}

Table 1 shows that the $\mathrm{pH}$ found in the ES was around 6.0, while in the sediment from Fundão (DS) it was registered at $\mathrm{pH} 8.0$, contrasting with the acidic soils ( $\sim \mathrm{pH} 4.5)$ of the Atlantic Forest (PS). Among the 15 settler properties (ES) studied, the majority presented higher levels of $\mathrm{P}, \mathrm{K}, \mathrm{Ca}, \mathrm{Mg}$ and organic matter than the DS, which may be attributed to the agricultural fertilizer used at these sites. The sodium content was also found to be high in most properties compared to the forest soil (PS), where it was very low (4mg/ kg), suggesting that the source of $\mathrm{Na}$ is the dam tailings [2], since this element is not used in agricultural fertilization procedures. The N-NH4 content was also found to be elevated in the settler properties (ES), but similar to the PS. In contrast, N-NO3 was strongly inhibited (Table 1), a finding also reported by [2] and [9] in dam tailing sediments. Higher levels of N-NH4 probably derive from ether-amine, but the low N-NO3 contents suggest a lack of soil-nitrifying bacteria as a result of a decline of microbial communities and diversity due to the dam tailings [2], [9], [13]. Sodium toxicity may inhibit plant growth, induce senescence and cause plant mortality [14] and ammonium may be toxic to native and agronomic species[15]. Thus, these contaminants in the settler areas may explain the reduction of agricultural productivity by 50\% and of fishing in their properties, as shown in Fig. 2 A and B, and also in reports by ANVISA (Brazilian Health Regulatory Agency) [16] . However, such toxicity may be remediated by both woody and agro-pastoral species, as shown by [8] -[9]. Such remediation strategies allowed the recovery of soil fertility and significant improvement in plant growth [9]. Besides, the impact of flooding may be controlled by restoring riparian forests using a buffer zones system [11]. Thus, such a strategy is strongly recommended to protect the productive properties of the rural settlements at Ipaba, as schematized in Fig. 3A. 
A

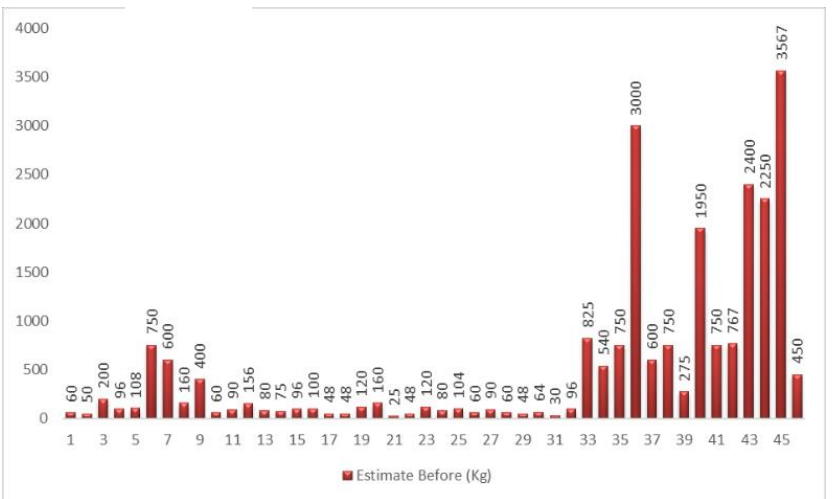

B

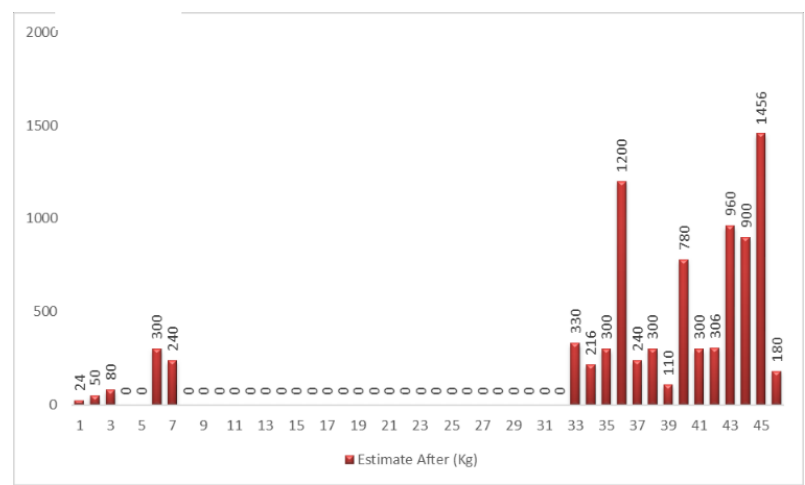

Fig. 2: Estimation of rural production and income of settler properties before (A) and after (B) Fundão rupture.

In addition, Ipaba hosts a large population with no access to fundamental schooling $(58,4 \%)$ and only $2.1 \%$ of the population has attained college. Although there are several schools in the town for different academic levels, such as kindergarten ( 7 schools with 541 students); elementary schools (8 schools and 2384 students), high school ( 3 schools and 804 students), no technical school was registered. Besides the agronomic and fishing activities, CENIBRA, a forest company dedicated to cellulose production, constitutes a potential source of economic activities diversification for the settlements. In this perspective, technical courses focused on agriculture and forestry formation would provide this population with knowledge and skills to improve their agricultural and forestry activities, and this is one of the goals of the rehabilitation plan, as demonstrated in the schematic view of the recovery plan for the rural settlers area in Fig. 3 A.

Therefore, based on the environmental and social impact assessments, we propose: 1) the rehabilitation of the riparian forests using a zones system (Figs. $3 \mathrm{~B}$ and $3 \mathrm{C}$ ) to protect the settlers area against the contaminated flooding from the Doce River; 2) the remediation of contaminated soil using phyto, chemical and physical remediation procedures in order to recover the agricultural activities at these sites (Fig. 3 B); 3) the establishment of an agro-forestry technical school and a social association in order to provide the population with knowledge, skills and self-sufficiency for the implementation of such rehabilitation, and enabling the commercialization of products as proposed in Fig. $3 \mathrm{~B}$. 
Table 1: Chemical analysis of soils: settler properties (ES), preserved (PS), disturbed (DS) sites. Analysis of variance ANOVA was applied and means were compared by Tuckey's test (Different lowercase letters per column indicate differences at 5\%)

\begin{tabular}{|c|c|c|c|c|c|c|c|c|c|}
\hline $\begin{array}{l}\text { Site } \\
\text { Variables }\end{array}$ & pH & $\begin{array}{c}P \\
\left(\mathrm{mg} / \mathrm{dm}^{3}\right)\end{array}$ & $\begin{array}{c}\mathrm{K} \\
(\mathrm{mg} / \mathrm{kg})\end{array}$ & $\begin{array}{c}\text { Ca } \\
(\mathrm{mg} / \mathrm{kg})\end{array}$ & $\begin{array}{c}\mathrm{Mg} \\
(\mathrm{mg} / \mathrm{kg})\end{array}$ & $\begin{array}{c}\text { OM } \\
(\mathrm{g} / \mathrm{kg})\end{array}$ & $\begin{array}{c}\mathrm{Na} \\
(\mathrm{mg} / \mathrm{kg})\end{array}$ & $\begin{array}{l}\text { N-NH4 } \\
\text { (mg/kg) }\end{array}$ & $\begin{array}{l}\text { N-N03 } \\
(\mathrm{mg} / \mathrm{kg})\end{array}$ \\
\hline PS & $4.6 \mathrm{a}$ & $6.7 \mathrm{fgh}$ & $75.3 \mathrm{de}$ & $278 . f$ & $72.0 \mathrm{~cd}$ & $8.7 \mathrm{de}$ & $4.66 \mathrm{e}$ & $6.43 \mathrm{bc}$ & $42.3 \mathrm{a}$ \\
\hline DS & $8.13 \mathrm{c}$ & $4.3 \mathrm{gh}$ & $7.3 \mathrm{~h}$ & $183.6 \mathrm{~g}$ & $10.0 \mathrm{e}$ & $0.9 \mathrm{~g}$ & $55.3 \mathrm{a}$ & $2.1 \mathrm{~cd}$ & $2.08 \mathrm{de}$ \\
\hline ES 1 & $6.2 b$ & $3.0 \mathrm{~h}$ & $46.8 \mathrm{ef}$ & $320.4 \mathrm{ef}$ & $93 \mathrm{bc}$ & $10.33 \mathrm{de}$ & $9.38 \mathrm{~d}$ & $4.6 \mathrm{c}$ & $4.6 \mathrm{~cd}$ \\
\hline ES 2 & $5.9 \mathrm{~b}$ & 4.27(h & $31.2 \mathrm{fg}$ & $340.6 \mathrm{e}$ & $72.9 \mathrm{~cd}$ & $9.03 \mathrm{de}$ & $11.4 \mathrm{~cd}$ & $1.9 \mathrm{~cd}$ & $3.4 \mathrm{~cd}$ \\
\hline ES 3 & $5.6 b$ & $5.0 \mathrm{gh}$ & $72.8 \mathrm{de}$ & $367.4 \mathrm{de}$ & $93.1 \mathrm{bc}$ & $10.3 \mathrm{de}$ & $9.6 \mathrm{~cd}$ & $6.3 \mathrm{bc}$ & $4.5 \mathrm{~cd}$ \\
\hline ES 4 & $5.9 \mathrm{~b}$ & $3.3 \mathrm{~h}$ & $30.8 \mathrm{fg}$ & $354.0 \mathrm{e}$ & $76.9 \mathrm{~cd}$ & $9.1 \mathrm{de}$ & $10.9 \mathrm{~cd}$ & $4.6 \mathrm{bcd}$ & $3.1 \mathrm{~cd}$ \\
\hline ES 5 & $6.01 \mathrm{~b}$ & $3.7 \mathrm{~h}$ & $84.5 \mathrm{~d}$ & $407.4 \mathrm{~cd}$ & $105.3 \mathrm{bc}$ & $17.0 \mathrm{~b}$ & $11.6 \mathrm{~cd}$ & $7.32 \mathrm{bc}$ & $5.0 \mathrm{~d}$ \\
\hline ES 6 & $6.1 \mathrm{~b}$ & $4.9 \mathrm{gh}$ & $34.5 f g$ & $407.4 \mathrm{~cd}$ & $97.3 b c$ & $11.3 \mathrm{cde}$ & $11.9 \mathrm{~cd}$ & $6.7 \mathrm{bcd}$ & $5.2 \mathrm{~cd}$ \\
\hline ES 7 & $5.9 \mathrm{~b}$ & $41.3 \mathrm{a}$ & $111 \mathrm{c}$ & $1115.5 \mathrm{a}$ & $158.8 \mathrm{ab}$ & $22.5 a$ & $11.9 \mathrm{~cd}$ & $11.3 \mathrm{ab}$ & $2.5 \mathrm{cde}$ \\
\hline ES 8 & $6.0 \mathrm{~b}$ & $6.8 \mathrm{fgh}$ & 48.1ef & 320.6def & $64.8 \mathrm{~d}$ & $5.5 f$ & $9.0 \mathrm{~cd}$ & $2.9 \mathrm{~cd}$ & $4.0 \mathrm{~cd}$ \\
\hline ES 9 & $5.9 \mathrm{~b}$ & $29.0 \mathrm{~b}$ & $180 \mathrm{~b}$ & $741.4 \mathrm{~b}$ & $178.2 \mathrm{a}$ & $21.33 \mathrm{a}$ & $22.8 \mathrm{~b}$ & $13.3 \mathrm{a}$ & $10.8 \mathrm{~b}$ \\
\hline ES 10 & $5.5 b$ & 8.0 efg & $74.1 \mathrm{de}$ & $440 \mathrm{~cd}$ & $121.6 \mathrm{bc}$ & $12.0 \mathrm{~cd}$ & $12.5 \mathrm{c}$ & 7.99abc & $2.8 \mathrm{~cd}$ \\
\hline ES 11 & $5.9 \mathrm{~b}$ & $28.0 \mathrm{~b}$ & $59.1 \mathrm{e}$ & $407.5 \mathrm{~cd}$ & $85.0 \mathrm{~cd}$ & $12.3 \mathrm{~cd}$ & $11.14 \mathrm{c}$ & $3.6 \mathrm{~cd}$ & $2.72 \mathrm{~cd}$ \\
\hline ES 12 & $5.9 \mathrm{~b}$ & $20.0 \mathrm{c}$ & $72.0 \mathrm{de}$ & $440.0 \mathrm{~cd}$ & $84.0 \mathrm{~cd}$ & $12.3 \mathrm{~d}$ & $11.42 \mathrm{c}$ & $4.4 \mathrm{bc}$ & $7.5 \mathrm{bc}$ \\
\hline ES 13 & $6.3 b$ & $17.0 \mathrm{~cd}$ & $328.0 \mathrm{a}$ & 413. $1 \mathrm{~cd}$ & $84.7 \mathrm{~cd}$ & $14.4 \mathrm{bc}$ & $27.2 \mathrm{~b}$ & $9.5 \mathrm{ab}$ & $2.4 \mathrm{~d}$ \\
\hline ES 14 & $6.24 b$ & $13.0 \mathrm{de}$ & $116.01 \mathrm{c}$ & $420 c$ & $92.0 \mathrm{~cd}$ & $10.0 \mathrm{de}$ & $22.8 \mathrm{~b}$ & $3.9 \mathrm{~cd}$ & $2.04 \mathrm{~d}$ \\
\hline ES 15 & $6.01 \mathrm{~b}$ & 8.7efg & $21.7 \mathrm{gh}$ & $426.7 \mathrm{~cd}$ & $28.0 \mathrm{e}$ & $8.7 \mathrm{e}$ & $9.01 \mathrm{~cd}$ & $3.9 \mathrm{~cd}$ & $5.2 \mathrm{~cd}$ \\
\hline
\end{tabular}



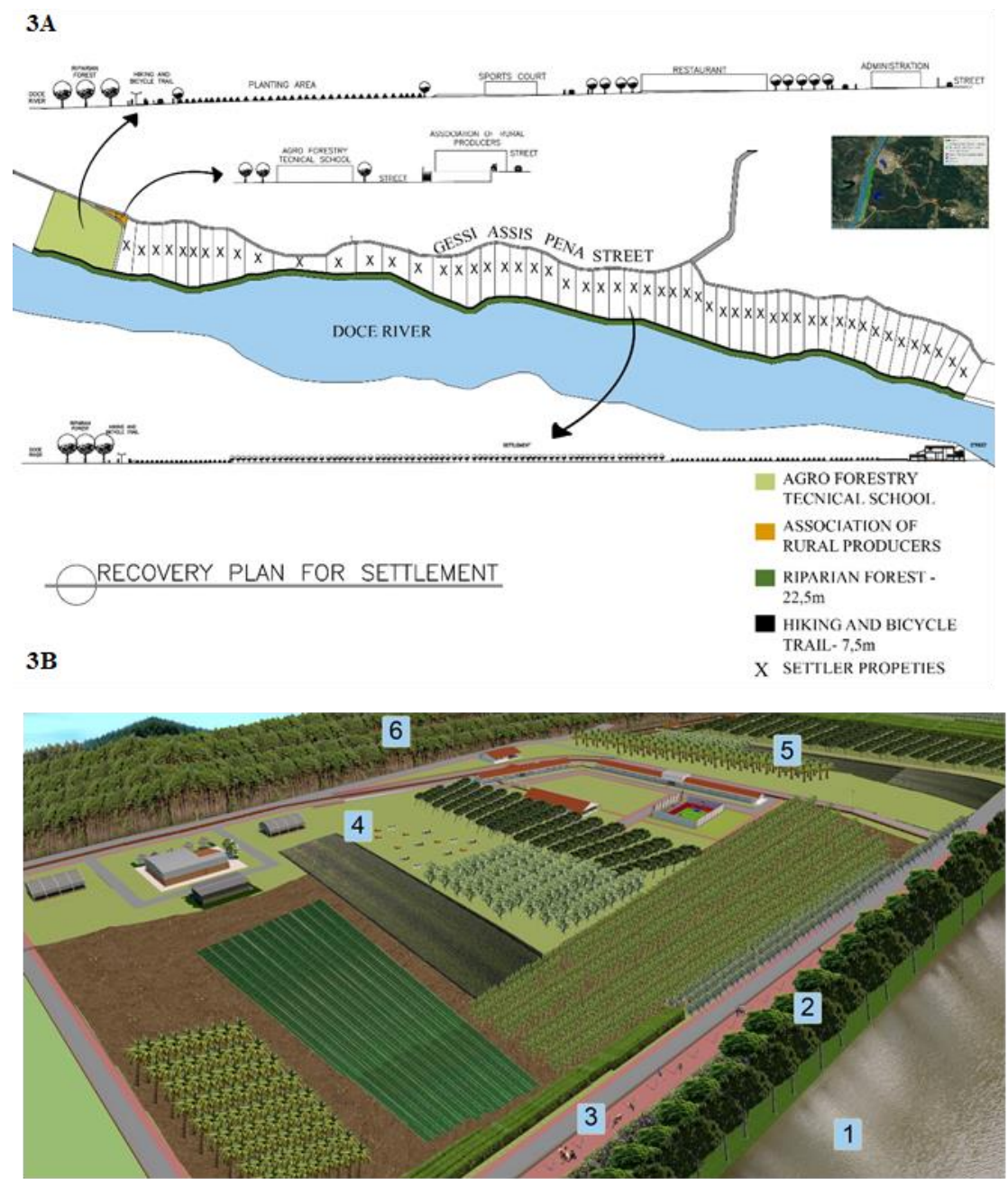

$3 \mathrm{C}$

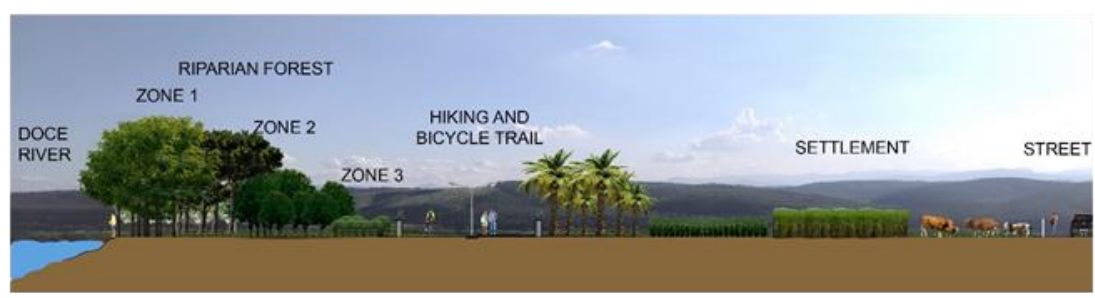

Fig. 3: A: Schematic recovery plan for settlement site in Ipaba. B: Settlement recovery plan: 1. Doce River, 2. Riparian forest, 3. Hiking and bicycle trail, 4. Agro-forestry technical school, 5. Settlement, 6. Reforestation site (Cenibra). C: Schematic implantation of a protective riparian buffer forest with zones associated with productive rural site in an Ipaba settlement.

\section{Conclusion}

In conclusion, a post-disaster recovery plan is needed, including the restoration of riparian forests, the remediation of agricultural lands to alleviate contaminant toxicity and restore agricultural activities, and the provision of skills, knowledge and infra-structure for local populations. These strategies will hopefully help the settler communities through the environmental, social and economic rehabilitation procedures. 


\section{Acknowledgements}

This work was supported by the Architecture School / Graduation Program in Built Environment and Sustainable Heritage and the Biological Institute, Federal University of Minas Gerais (UFMG). The authors are grateful to Coordenação Coordenação de Aperfeiçoamento de Pessoal Docente (CAPES) for the scholarship.

\section{References}

[1] IBAMA. Instituto Brasileiro do Meio Ambiente e Recursos Naturais Renováveis. (2019, May 20). Laudo Técnico Preliminar - Impactos ambientais decorrentes do desastre envolvendo o rompimento da barragem de Fundão, em Mariana, Minas Gerais. [Online].Available: https://jornalismosocioambiental.files.wordpress.com/2016/01/laudopreliminar-do-ibama-sobre-mariana.pdf

[2] O.S.H. Santos, F.C. Avellar, M. Alves, R.C. Trindade. M.B. Menezes, M.C. Ferreira, G.S. França, J.Cordeiro, F.G. Sobreira, I.M. Yoshida, P.M. Moura, M.B. Baptista, M.R. Scotti. Understanding the Environmental Impact of a Mine Dam Rupture in Brazil: Prospects for Remediation. J. Environ. Qual. vol. 48, pp. 439-449. 2019.

[3] A. C.T. Bonecker, M.S. Castro, P. G. Costa, A. Bianchini, S.L.C. Bonecker. (2015, May 08). Larval fish assemblages of the coastal area affected by the tailings of the collapsed dam in southeast Brazil Regional Studies in Marine Science [Online].Available:https://www.researchgate.net/publication/336036263_Larval_fish_assemblages_of_the_coastal_ar ea_affected_by_the_tailings_of_the_collapsed_dam_in_southeast_Brazil

[4] A.C. Araujo, P.R.M.Viana, A.E.C. Peres. Reagents in iron ores flotation. Minerals Engineering. vol. 18, pp. $219-224$. 2005.

[5] D.M. Araújo, M.I. Yoshida, J.A. Takahashi, C.F. Carvalho, F. Stapelfeldt, Reciclagem de aminas na flotação de minério de ferro. REM, Rev. Esc. Minas. v. 61, no. 4, pp. 455-460. 2008.

[6] C.V.A. Santolin, V.S.T. Ciminelli, C.C. Nascentes, C.C. Windmöller. Distribution and environmental impact evaluation of metals in sediments from the Doce River Basin, Brazil. Environ Earth Sci. vol.74, pp.1235-1248. 2015.

[7] M.B.B. Guerra, B.T. Teaney, B.J. Mount, D.J. Asunskis, T.J. Brennan, R.J. Barker, E.S.Eliana, E.G.R. S. Carlos. Postcatastrophe Analysis of the Fundão tailings dam failure in the Doce River system, Southeast Brazil: Potentially toxic elements in affected soils. Water Air Soil Pollut. vol. 228, no. 7, pp. 252-264. 2017.

[8] M. R. Scotti, S. S. Avila, L. Mendes, T. J. Lacerda, S. L. L. Silva, A. C. Antão, A. R. F. Gomes, M. B. Medeiros, S. Alvarenga, C. H. B. Santos, E. C. Rigobelo. First Report of Field Remediation of Contaminated Tailings from the Collapsed Fundão Dam in Brazil. Proceedings of the 5th World Congress on New Technologies (NewTech'19).2019.

[9] M.R., Scotti, A. R. Gomes, T.J. Lacerda, S.S. Ávila, S. L.L. Silva, A. Antão. A.G.P. Santos, M. Medeiros, S. Alvarenga, C.H.Santos, E. Rigobelo. Remediation of a riparian site in the Brazilian Atlantic forest reached by contaminated tailings from the collapsed Fundão dam with native woody species. Integrated Environmental Assessment and Management. vol. 16, pp. 1-17. 2020.

[10] IBGE - INSTITUTO BRASILEIRO DE GEOGRAFIA E ESTATÍSTICA, (2019, May 08). Pesquisa sobre a cidade de Ipaba, MG. [Online].Available:https://cidades.ibge.gov.br/brasil/mg/ipaba/pesquisa/13/78117?indicador=5913.

[11] A.C. Kimura, M.B. Baptista, M.R. Scotti. Soil humic acid and aggregation as restoration indicators of a seasonally flooded riparian forest under buffer zone system. Ecological Engeneering. vol 98, pp.146-156. 2017.

[12] EMBRAPA, (2019, May 08). Manual de métodos de análise do solo. [Online].Available: https://www.agencia.cnptia.embrapa.br/Repositorio/Manual+de+Metodos_000fzvhotqk02wx5ok0q43a0ram31wtr.pdf

[13] F. R. Segura, E. A. Nunes, F. P. Paniz, A. C. C. Paulelli, G. B. Rodrigues, G. U. L. Braga. 2016. Potential risks of the residue from Samarco's mine dam burst (Bento Rodrigues, Brazil), Environ. Pollut. vol. 218, pp. 813-825. 2016.

[14] J. K. Zhu. Plant salt tolerance. Trends Plant Sci. vol.6, pp. 66-71. 2001.

[15] D.T. Britto, H.J. Kronzucker. NH4 + toxicity in higher plants: A critical review. J Plant Physiol. vol. 159, PP. $567-584$. 2002 
[16] ANVISA, (2020, May 15). Nota técnica redução da produção agrícola e da pesca em áreas atingidas pelo rompimento da barrage de Fundão. [Online].Available: http://portal.anvisa.gov.br/documents/2857848/5519746/SEI_ANVISA++0596655+-+Nota+T\%C3\%A9cnica+-+Pescado+Rio+Doce.pdf/86d2736c-cefc-40c3-9c70-4cb48fd7df9d 